\title{
Code-switching: Beliefs and Attitudes of Albanian pre service English teachers
}

\author{
Doi:10.5901/jesr.2014.v4n2p384
}

\author{
Prof.Asc. Ph.D. Elida Tabaku \\ Faculty of Foreign Languages \\ University of Tirana \\ email: lidatabaku@yahoo.com
}

\begin{abstract}
Code switching is a phenomenon mostly seen in bilingual and multilingual situations. It happens all the time in language classes. There has been a lot of discussion and research on how much this should be allowed. The common questions that arise are why language teachers choose to shift from one code to the other, how much this is conditioned and affected by students language ability and how this can be exploited to teach language communicatively. A better understanding of the role of code switching in language classes will make student teachers more aware of this phenomenon. They will be able to use a variety of language activities in the class to teach language skills and metalinguistic strategies. $A$ study was carried out about beliefs and attitudes of Albanian pre service teachers on the above mentioned questions. 80 first year students in the Teacher Education Master program were given a semi structured questionnaire with items on their experience and reflections. They wrote about the actual use of the mother tongue in the English classes, the reason of its use and the advantages and disadvantages of code switching in the language class. The paper presents the data from this study, an analysis and concludes with discussion and suggestions of how to deal with this issue in language teacher education programs and in the classroom practice.
\end{abstract}

Keywords: Code switching , teacher education, language classes, native language.

\section{Introduction}

Foreign language teaching is an important subject of our school curricula, where English is the first foreign language taught. In order to meet students' needs for communicative language learning it is important to improve the quality of language teaching through improving the quality of teacher education. One of the issues which concerns language teachers and teacher educators is code switching, i.e. the use of mother tongue in the class. Code switching is a phenomenon mostly seen in bilingual and multilingual situations out of the class. Usually, bilinguals mix the two languages they are fluent at when they speak. We hear Albanians that mix Albanian and Turkish, Albanian and Italian or Albanian immigrants mixing Albanian and English. This is a common phenomenon and used by bilinguals to contextualize talk in interaction. Sociolinguistics is the most common field of linguistics in which studies of code switching are conducted, but it is a phenomenon that widely occurs in language teaching as well, usually in monolingual classes such as the case of Albanian schools. Numan and Carter define this term as "a phenomenon of switching from one language to another in the same discourse" (2001). This is seen all the time in language classes. When students do not know a word or how to express their ideas they use words from their mother tongue. In addition, teachers use it in the class not only in elementary education, but also in higher education. This is a known fact in our schools and the discussions and research focus on why language teachers choose to shift from one code to the other, how much this is conditioned and affected by students language ability and how this can be exploited to teach language communicatively.

\section{Literature review}

Code switching has been defined as "the juxtaposition within the same speech exchange of passages of speech belonging to two different grammatical systems of subsystems."( Gemperz,1982). Code switching is also defined as the insertion of a word or phrase of a language other than that being spoken into a single sentence, or the movement back and forth between two languages or dialects. Trudgill states that "speakers switch to manipulate or influence or define the situation as they wish, and to convey nuances of meaning and personal intention" (Trudgill , 2000). Cook (2000) in his definition states that it is "going from one language to the other in mid speech when both speakers know the same two languages" Myers-Scottons (2006) general definition of code switching is "the use of two languages varieties in the 
same conversation". Thus code-switching is not random because there are certain important structures where codeswitches do occur or do not occur. And it is not just 'forgetting' a word, it is an active choice to achieve a social or linguistic aim through conversational strategy. Code switches show competence not incompetence

\section{Why do people switch codes}

Seen from a sociolinguistics perspective code switching performs a variety of functions such as to emphasize a particular point, to substitute a word in place of unknown word in the target language, to express a concept that has no equivalent in the culture of the other language, to reinforce a request, to clarify a point, to express identity and communicate friendship, to ease tension and inject humour into a conversation, to introduce certain topics ( Baker, 2006) .

First, it is used to hide fluency in the second language. Second, code-switching is used to show switching from informal situations to formal situations. Third, code-switching is used to show authority, mainly in the family. Fourth, code-switching is used to relate to other speakers in different situations.

Code switching is a way of modifying language for the sake of personal intentions, such as building interpersonal relationships among members of a bilingual community, bridging gaps with interlocutors who share the same ethnocultural identity. It is a strategy employed by bilinguals.

\section{Why do teachers switch codes}

Many of the reasons why code switching happens in a bilingual environment exist in a language class as well. In every day practice it is seen that in all levels of education L1 is widely used, sometimes unconsciously for different reasons in addition to the ones that make bilinguals switch codes.

In foreign language teaching literature there are controversial opinions regarding the use of L1 in the class.

Code switching has been frowned upon for two reasons. First, using $L 1$ in the class is considered as a delaying factor to language acquisition and contrary to the natural way of learning the language. Learners may become dependent on teachers' code-switching. They may not develop their skills of guessing and inferring from the context. It might also influence the way learners communicate in the foreign language later. Second, code switching has been considered as a strategy used by poor language learners and teachers that use the mother tongue to conceal their language deficiency.

As the class is a language community that aims at creating possibilities for its members to learn and use language by providing meaningful input to them, it is logical that the same 'rules' that function in a bilingual setting will work here. Cook (2001) says "Teachers should be clear in their minds that they are usually teaching people how to use two languages, not how to use one in isolation....Rather, the aim is people who can stand between two viewpoints and between two cultures, a multi-competent speaker who can do more than any monolingual."

Code switching serves some basic functions which may be beneficial in language learning environments.

The teachers use code-switching in language classrooms, according to Jacobson (1983) to provide students with sufficient input in the two languages for them to derive grammatical and lexical information, to help students of different language levels to understand the explanation, to provide a way of establishing equal prestige for both languages within the classroom setting, and then is likely to encourage a balanced distribution of the two languages, and to keep the students on task .

Usually English teachers code switch in order to explain grammar. By using the mother tongue, i.e. by switching codes the teacher helps students to transfer their knowledge in the mother tongue into the foreign language so "a teacher can exploit students' previous L1 learning experience to increase their understanding of L2"( Cole, 1998). The teacher also uses it to signal the transition from one stage of the lesson to the other, to give instructions, to manage the class.

Thus code switching in a language class has the function of topic switch, affective functions, and repetitive functions (Sert, 0. 2005).

Students switch codes to find the equivalent of the unknown words of the target language to overcome the deficiency in language production, to keep their conversation going on. They also use code switching to emphasize or reinforce what they want to say or the message taken. They repeat to understand the language input better and to show the teacher that it is clearly understood by him.

A number of studies see code switching in classrooms not only just normal but a useful tool of learning. As Cook (2001) stated that bilinguals always shift from one language to the other, and foreign language learners always translate 
in their minds, why we must not use translation in the class. Studies have shown that code switching is used as an effective strategy to achieve a number of communicative and metalinguistic ends, to understand concepts and to explore their ideas .

\section{Research questions}

The study was based on the following research questions with the aim of analyzing pre service teachers' beliefs and attitudes to code switching.

Why do language teachers choose to shift from one code to the other, in other words why do they shift from English to Albanian or vice versa?

How much is code switching conditioned and affected by students language ability?

\section{Methodology}

The study is a both a both qualitative and quantitative research. The data were collected form the questionnaires which consisted of 21 items, seven on beliefs about code switching, seven on functions of use of code switching in the class and seven others on factors affecting code switching. These statements highlighted the functions of code switching and participants had to tick the one they evaluated better.

Open ended questions consisting of three items, which demonstrated students'opinions based on personal experience and reflections.

\section{Participants}

The participants involved in this study are 80 teacher students attending the first year of the Master', in English Language Teacher Education, in the Faculty of Foreign languages, University of Tirana. They have taken the Bachelor degree, have a good mastery of language, with an average age of 22.5 years. Only $10 \%$ work as teachers, while others have had sporadic teaching experience in private language courses.

\section{Data analysis and discussion}

The findings from the questionnaires and the open ended questions reflect the opinion and belief of the students regarding code switching in class.

Table 1 consists of seven items regarding statements on code switching.

Most of them ( $60 \%$ ) agree that Albanian should be used and only $15 \%$ ( 8 participants) disagree with this.

$70 \%$ of the participants strongly agreed that they could understand and learn better if teachers switched codes between Albanian and English, whereas $30 \%$ stated that it was beneficial for them to be taught in the foreign language.

The high percentage ( $70 \%$ ) of students preferring a mixing of both English and Albanian in class shows that the use of L1 affects their learning and their understanding.

The results show that most students are in favour of L1 use in the class.

Table 1. Statements on code switching.

\begin{tabular}{|l|}
\hline $\begin{array}{l}\text { 1.How often do you think Albanian should be used in the English classroom? } \\
\text { never } 5 \% \text { very rarely } 50 \% \quad \text { sometimes } 60 \% \quad \text { fairly frequently } 30 \%\end{array}$ \\
\hline 2.Code switching and its effects in learning English \\
- Mixing Albanian and English helps me to learn English better $70 \%$ \\
-Mixing Albanian and English hinders my progress in English helps 30\% \\
\hline 3.Code switching and teacher's image among students \\
- I respect teachers who use Albanian in class $45 \%$ \\
- I do not I respect teachers who use Albanian in class $55 \%$ \\
\hline
\end{tabular}




\section{Code switching and its effect on Albanian language}

- It helps me to understand the difference between languages $80 \%$

- It helps me to be aware of borrowings in Albanian $50 \%$

\section{Code switching and its effects on learning}

-Teaching in English increases my chances of having a better performance in grammar, reading $40 \%$

- Teaching in English and Albanian increase my chances of having a better performance in grammar, reading . $60 \%$

\section{Code switching and learning of new words}

- It helps to remember the new words $40 \%$

- It helps to understand new words better $70 \%$

7.What makes you decide how much code switching to use in the class?

- Students' level of language $80 \%$

- Their attitude in class $\quad 30 \%$

-Lesson learning objective $59 \%$

\section{When must we use Albanian in the class?}

In answer to the open ended questions most of the participants ( $80 \%$ ) reported that they strongly agree to the use of L1 in. They also think that is a useful tool in checking their comprehension. They write that code switching not simply saves them time but gives a clear meaning of the item taught.

65 of the participants see the translation of words, phrases and sentences as the first step to text comprehension, mother tongue can be used to explain meaning as well.

Code switching is important in class management, they write that it is used to keep discipline, to introduce an activity, to promote class activities, to negotiate meanings, to praise and encourage or to criticize.

\section{How should code switching be exploited?}

The students strongly agreed that the use of L1 must take up most of the time. It should be used in clarifying meaning in different discussions, in explaining new items. This must be according to the language level of students.

\section{How much should a teacher use L1?}

They value the cases when L1 is used to aid the teaching and learning, but not as the main teaching language. They value teachers that code switch for pedagogical aims,

The second part of the questionnaire is made up of seven items regarding the functions of code switching in class.

Table 2. Functions of use of code switching in the class

\begin{tabular}{|c|l|c|c|c|}
\hline No & Function of code switching & N & respondents & $\%$ \\
\hline 1 & Check comprehension & 80 & 45 & 52 \\
\hline 2 & Highlight important points & 80 & 40 & 50 \\
\hline 3 & Teach grammar and abstract words & 80 & 70 & 87 \\
\hline 4 & Manage class & 80 & 48 & 60 \\
\hline 5 & Give instructions & 80 & 28 & 35 \\
\hline 6 & Maintain discipline in class & 80 & 24 & 30 \\
\hline 7 & Save time & 80 & 80 & 100 \\
\hline
\end{tabular}


About $97 \%$ of teacher students report that the L1 is mainly employed to teach grammar and abstract words. This is a much favored function of the $L 1$ in foreign language class and the purpose is to make the class be more time-cost efficient and easier to be understood, that is why $100 \%$ of them see as its function, saving time. As to other functions of the $\mathrm{L} 1,50 \%$ report Albanian is used to highlight important points, $52 \%$ of them to check comprehension, $28 \%$ of them to give instructions and $24 \%$ of them to organize tasks and classes.

Table 3 . Factors affecting code switching

\begin{tabular}{|c|l|c|c|c|}
\hline No & Factors affecting code switching & N & respondents & $\%$ \\
\hline 1 & Teachers' foreign language proficiency & 80 & 80 & 100 \\
\hline 2 & Students' proficiency & 80 & 80 & 100 \\
\hline 3 & Teaching methods used & 80 & 70 & 87 \\
\hline 4 & Teaching activities conducted & 80 & 68 & 85 \\
\hline 5 & Class size & 80 & 60 & 75 \\
\hline 6 & Lesson content & 80 & 48 & 60 \\
\hline 7 & Learning objectives & 80 & 40 & 50 \\
\hline
\end{tabular}

Regarding factors that affect code switching all participants agree in $100 \%$ of the cases that teachers'and students' language proficiency are the reason of code switching.

The other factors mentioned in order were methods used by teachers noted by $87 \%$ of the participants, teaching activities conducted by $85 \%$, class size by $75 \%$, lesson content by $60 \%$ and learning objectives by $50 \%$.

In answer to the first open ended questions 'When must we use Albanian in the class?' most of the participants ( $80 \%)$ reported that they strongly agree to the use of L1 in. They also think that is useful tool in checking their comprehension. They write that code switching not simply saves them time but gives a clear meaning of the item taught.

65 of the participants see the translation of words, phrases and sentences as the first step to text comprehension, mother tongue can be used to explain meaning as well.

Code switching is important in class management, they write that it is used to keep discipline, to introduce an activity, to promote class activities, to negotiate meanings, to praise and encourage or to criticize.

Regarding the question of how to exploit switching the students strongly agreed that the use of L1 must not take up most of the time. It should be used in clarifying meaning in different discussions, in explaining new items. This must be according to the language level of students.

They value the cases when L1 is used to aid the teaching and learning, but not as the main teaching language. They value teachers that code switch for pedagogical aims. They are against the overuse of mother tongue in the class. Participants of the study mentioned other cases they thought suitable to code switch in the class such as giving instructions; questioning and giving answers; criticism; telling jokes; praising; translating; providing hints; giving opinions.

\section{Conclusion}

The findings from this study show that teacher students recognize the functions of code switching in class and have a positive attitude to it.

Code switching exists in language classes. L1 has been used in language classes even in time when it was strictly banned. Code switching is a supporting element in communication of information and in social interaction; therefore serves for communicative purposes in the way that it is used as a tool for transference of meaning. 
The participants in this study believe that code switching plays an important function in language learning and teaching. In an educational environment where the students and teachers share the same language it is easier for the teachers and students to switch codes.

They consider that it is important to introduce new topics, to explain new items, especially grammar , to manage classes, to give instructions, to transmit meaning, to praise and encourage students.

Students use code switching to clarify ideas, to repeat, to bridge gaps in communication.

$\mathrm{CS}$ is a teaching strategy in EFL classrooms for the different functions it serves in

teaching a foreign language. L1 use in EFL classrooms should not be discouraged. The benefits it brings to the class are a strong arguments in favour of its use to help students in learning a foreign language.

\section{References}

Baker, C. (2006). Foundations of Bilingual Education and Bilingualism, Multilingual Matters LTD.

Cole, S .1998. The Use of L1 in Communicative English Classrooms. The Language Teacher, 22:11-13

Cook, V. (2001). Second Language Learning and Language Teaching. London, Arnold.

Gemperz, J. (1982). Discourse strategies. Cambridge, Cambridge UniversityPress.

Jacobson, R. (1983). Intersetential code switching: an educationally justifiable strategy. ERIC Document Reproduction Service No ED132 221.

Macaro, E. (2001). Analyzing student teachers" code-switching in foreign language classroom: Theories and decision making. Modern language Journal, 85, 531-548.

Myers-Scotton , C. (2006). Multiple voices: an introduction to Bilingualism, Blackwell publishing.

Numan, D. and Carter, D. 2001. Teaching English to Speakers of Other Languages. Cambridge: Cambridge University Press

Sert, O. 2005 The Functions of Code Switching in ELT Classroom. The Internet TESL Journal. Vol. XI, No. 8, http://iteslj.org/Articles/Sert-CodeSwitching.html

Trudgill, P. 2000. Sociolinguistics. London: Penguin 